\title{
Utilization of $\beta$-Glucans in Germinating Sclerotia of Sclerotinia sclerotiorum (Lib.) de Bary
}

\author{
Izumi SAITo* \\ 斎藤 泉*: Sclerotinia sclerotiorum (Lib.) de Bary の \\ 菌核発芽における $\beta$-グルカンの消費
}

\begin{abstract}
Despite many works on gemination of fungal sclerotia, few data have been published on the utilization of reserve foods. Sclerotia of Sclerotinia sclerotiorum are known to be rich in carbohydrates which mainly consist of $\beta$-glucans ${ }^{1,2)}$. They form many primordia of apothecial stipes within their tissue on germination ${ }^{3)}$, but the actual number of the produced apothecia closely relates to the sclerotial size or weignt ${ }^{4}$. Thus the apothecial output seems to depend on the amount of the carbohydrates, namely in insoluble form, in a sclerotium. Accordingly, the mobilization of insoluble carbohydrates should be an important metabolic process during sclerotial germination. This note describes a possible role of sclerotial $\beta$-glucans as a carbohydrate reserve for apothecial production by $S$. sclerotiorum.
\end{abstract}

Sclerotia were obtained from bean stem cultures and allowed to germinate as previously described ${ }^{5)}$. They were collected at intervals, and the any stipes or apothecia produced were removed from the sclerotia. A sample of $4 \mathrm{~g}$ of sclerotia (fresh weight) was crushed with a cooled mortar and pestle using quarts sands in a $0.1 \mathrm{M}$ acetate buffer, $\mathrm{pH}$ 5.0. The homogenate was then filled up to $40 \mathrm{ml}$ with the buffer and centrifuged at $2000 \times \mathrm{g}$ for $20 \mathrm{~min}$. The supernatant was used as an enzyme extract. The assay mixture contained $2.0 \mathrm{ml}$ of substrate $(0.5 \%), 1.0 \mathrm{ml}$ of enzyme extract and $1.5 \mathrm{ml}$ of acetate buffer. Laminarin ( $\mathrm{K}$ and $\mathrm{K}$ Laboratory), soluble starch, cellobiose and trehalose were used as the substrate for the determination of the activity of $\beta-1,3$ glucanase, amylase, $\beta$ glucosidase and trehalase, respectively. After the incubation of the mixture for $2 \mathrm{hr}$ at $37 \mathrm{C}$, the amount of liberated reducing sugars was determined colorimetrically with Somogi method ${ }^{6}$. $\beta$ Glucosidase activity was determined with Glucostat, a glucose oxidase reagent (Worthington Biochem. Corp.). All enzyme activities are expressed as $\mathrm{mg}$ of glucose equivalents liberated in $2 \mathrm{hr}$ at $37 \mathrm{C}$.

For the study on the consumption of carbohydrates, sets of sclerotia (each of $3 \mathrm{~g}$ in fresh weight) were allowed to germinate. Three sets were taken at intervals, and the produced apothecia were separated from the sclerotia to determine the respective dry weight. The weighed sclerotia were powdered for further determination of carbohydrates. A sample of the powdered sclerotia was

* Hokkaido Central Agricultural Experiment Station, Naganuma, Hokkaido, Japan.

* 北海道立中央農業試験場

1) Kitahara, M. and Taniguchi, Y. (1960). Res. Bull. Coll. Agr. Gifu Univ. 11: 127-132 2) Oi, S., Konishi, I. and Satomura, Y. (1965). Agr. Biol. Chem. $24: 317-321 . \quad 3)$ Saito, I. (1973). Trans. mycol. Soc. Japan (in press). $\quad$ 4) Bedi, K. S. (1963). J. Indian Bot. Soc. 42: 204-207. 5) Saito, I. (1969). Bull. Hokkaido Prefect. Agr. Exp. Stat. 19: 1-7. 6) Somogi, M. (1952). J. Biol. Chem. 195: $19 . \quad$ 7) Dubois, M., Gilles, K. A., Hamilton, J. K., Rebers, P. A. and Smith, F. (1956). Anal. Chem. 28: 350-356. 8) Eargle, D. R. (1947). Phytopathology 38: 142-150. 9) Le Tourneau, D. (1966). Mycologia 58: 934-942. 10) Cooke, R. C. (1969). Trans. Br. mycol. Soc. 52: 365-372. 11) Percival, E. (1970). In The Carbohydrates. 2nd ed. (Pigman, W. and Horton, D. eds.). Academic Press, New York. Vol. II B : 537-565. 
extracted successively with boiling $80 \%$ ethanol, hot water and $2 \mathrm{~N} \mathrm{NaOH}$ at room temperature. The residues of the final extraction were hydrolysed with $4 \mathrm{~N} \mathrm{HCl}$ at $100 \mathrm{C}$ and the resultant solution was used for the determination of alkali-insoluble carbohydrates. The total sugars in each fraction were determined with the phenol-sulfuric acid method7). Free reducing sugars in an ethanolsoluble fraction were determined with Somogi method ${ }^{6}$, and the amount of non-reducing sugars in this fraction was calculated as the difference between the total sugars and the free reducing sugars.
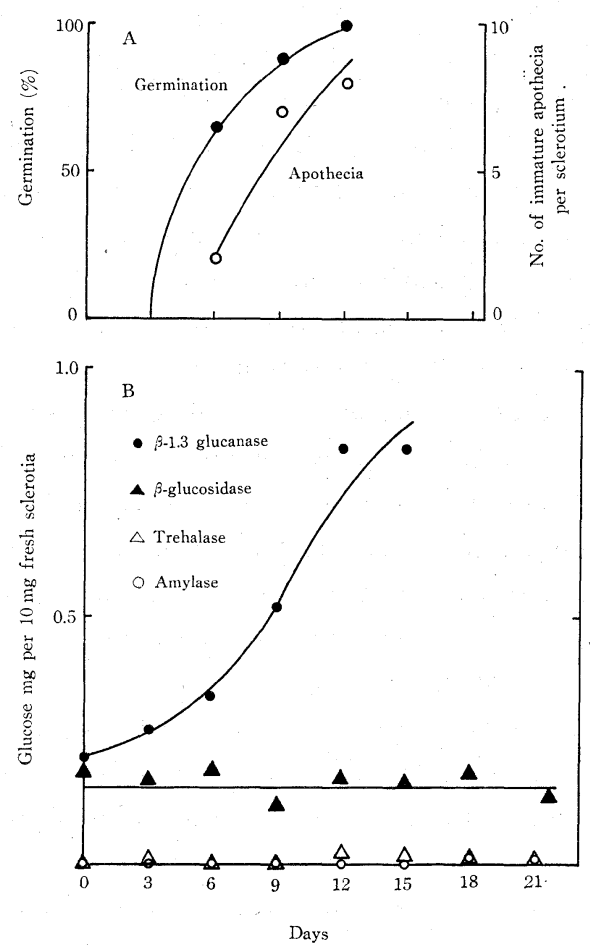

Fig. 1. The activity of various carbohydrases in sclerotia during the germination and apothecial production.
A) Germination and apothecial pro- duction.
B) Enzyme activities.
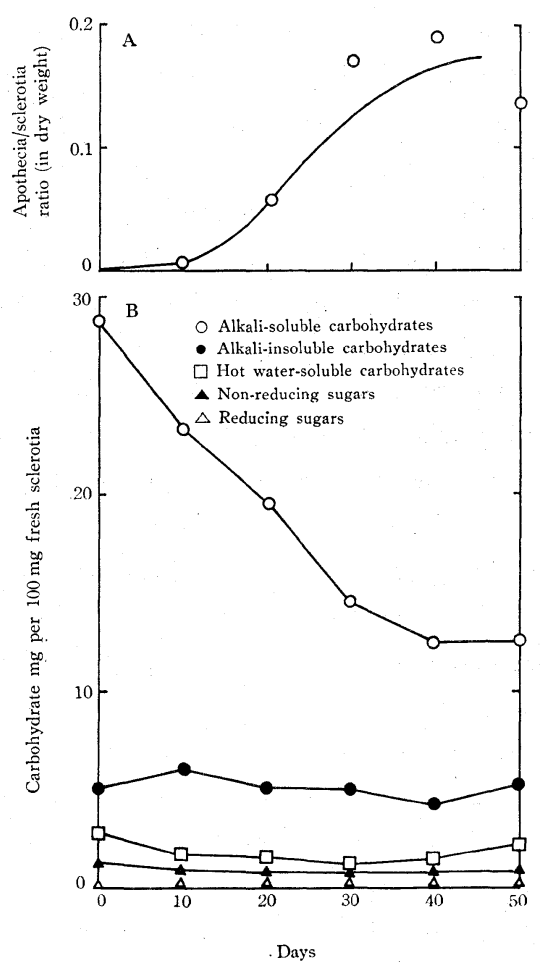

Fig. 2. Changes in various carbohydrate fractions of sclerotia during the germination and development of apothecia.
A) Apothecial production.
B) Quantitative changes of carbo- hydrates in sclerotia.

The changes in the activity of various carbohydrases in the sclerotia during germination are shown in Fig. 1. Mature sclerotia have weak but detectable activity of $\beta-1,3$ glucanase and $\beta$ glucosidase even before their incubation in a moist condition. The externally visible germination was beginning on the 5 th day of incubation and peaked on the 12 th day. The $\beta-1,3$ glucanase activity increased gradually with the beginning of germination. However, the increment of the activity was most pronounced at the later period of germination and rather paralleled by the apothecial development, while $\beta$-glucosidase activity remained at its initial level. Amylase and trehalase activities, in contrast, were very low during the germination period. Glycogen, a substrate for amylase, is believed to be a common reserve of fungi and, in fact, is utilized during the sclerotial germination of Phymatotrichum omnivorum in which a relatively high level of amylase activity was 
observed $^{8}$. The less activity of amylase in germinating sclerotia of $S$. sclerotiorum suggests that glycogen might not be involved in sclerotia or might be of minor importance as a reserve carbohydrate. It is surprising that trehalase activity is very low even in the most actively germinating sclerotia though trehalose is a major soluble sugar in the sclerotia of $S$. sclerotiorum ${ }^{9}$.

The apothecial production from sclerotia and the resulting changes in the carbohydrate constituents of sclerotia are shown in Fig. 2. The former is expressed as a dry weight ratio of apothecia to the parent sclerotia. Non-reducing sugars in the ethanol-soluble fraction appear to practically be trehalose since the other oligosaccharides were usually absent in the ethanol extracts ${ }^{9}$. However, quantitative change of the sugar was not pronounced during germination, contrary to the result in $S$. carreyana in which trehalose consumption was estimated by means of a paper chromatography ${ }^{10}$. The present data is still insufficient to reveal the role or the behaviour of trehalose in sclerotial germination. The hot water-soluble fraction was found to be a minor component of the insoluble carbohydrates. $\beta-1,3$ Glucanase treatment on the fraction resulted in a significant increase of reducing sugars, indicating the inclusion of a glucan containing $\beta-1,3$ linkages (unpublished). It is likely that alkali-soluble glucans may be partly dissolved with the hot water-extraction. Alkali-soluble carbohydrates appear to consist of the $\beta$-glucans isolated by several workers on the basis of the solubility characteristics ${ }^{1,2}$. As apothecial production progressed, the content of the glucans significantly decreased. This well corresponds to the increase in $\beta-1,3$ glucanase activity after the onset of sclerotial germination. The decay of sclerotia that frequently occurred at the later period of incubation might be due to the consumption of the glucans. Alkali-insoluble carbohydrates are also likely to be glucans, but these remained quantitatively unchanged during germination. These appear to be bound to the cell wall accompanied with chitin and less utilizable than alkali-soluble glucans. From these results, it is suggested that the mobilization of alkali-soluble glucans by the activated $\beta-1,3$ glucanase may be involved in supply system (s) of carbohydrates for apothecial production. Since $\beta$-glucans are usually considered as the structural polysaccharides of many fungi, further study is needed to determine whether or not those of easily utilizable form, as is usual with certain algae ${ }^{11)}$, occur in sclerotia.

The guidance and support of Professor Y. Satomura during the part of this work carried out in Osaka City University are gratefully acknowledged. I am also indebted to Dr. S. Oi and Dr. M. Taniguchi for their helpful suggestions.

(Received December 24, 1973) 